\title{
PROFIL KESULITAN BERTANYA PADA PROSES PEMBELAJARAN PERKEMBANGAN HEWAN MAHASISWA PENDIDIKAN BIOLOGI UNIVERSITAS ISLAM RIAU PEKANBARU
}

(The Profiles of Questioning Difficulty during Animal Development Study Process for Biology Education Student)

\author{
Oleh: Suryanti *) Sudarmi *) Salsabyla Fadheela *) \\ .yantiedu@uir.ac.id \\ Darmibio.uir@gmail.Com \\ Salsabylafadhela20@gmail.com
}

*) Program Studi Pendidikan Biologi, Universitas Islam Riau

\begin{abstract}
This study aims to determined factors of questioning difficulty during learning process on Animal Development study. The type of study was survey, using questionnaire, interview, and documentation as study's instrument. The population subject of this study was third semester student of Biology Education with total 70 students. Analysis method was using descriptive method. As the result of the study shown that questioning difficulty was affected by internal factor $56,21 \%$ categorized as adequately and affected by external factor by $61,14 \%$ categorized as high. The percentage of students who created question was $42,86 \%$ categorized, as adequately, students who were not raise question $57.14 \%$ categorized as adequately. During study process, student who able to make questions was at the level of: level C1 (9.64\%), level C2 (67,47\%), level C3 (14,46\%) and level C4 $(1,20 \%)$

Keywords: Questioning Difficulty Profiles, Internal and External Factors, Student who raised questions, Student who did not raise question, Question Level C1, C2, C3, and C4, Animal Development Study.
\end{abstract}

\section{PENDAHULUAN}

Usaha sadar untuk mendewasakan anak didik adalah pendidikan. Dengan demikian setiap usaha pendidikan mempunyai tujuan, walaupun tampa sadari tujuan itu telah dirumuskan secara eksplisit. Secara umum tujuan pendidikan yang akan dicapai untuk kedewasaan anak didik. Ciri kedewasaan itu bervariasi sangat diwarnai oleh pandangan masyarakat dan termasuk di dalamnya adalah pendidik (Slameto, 2015).

Belajar yang efektif dapat membantu mahasiswa untuk meningkatkan kemampuan yang diharapkan sesuai dengan tujuan intruksional yang ingin dicapai. Keseluruhan proses pendidikan di kampus, kegiatan belajar merupakan kegitan yang paling pokok. Berhasil tidaknya pencapaian tujuan pendidikan banyak bergantung kepada proses belajar ynag dialami oleh mahasiswa dalam kegiatan belajar mengajar. Keberhasilan penyelenggaraan pendidikan formal secara umum dapat diindikasikan apabila kegiatan belajar mampu membentuk pola tingkah laku peserta didik sesuai dengan tujuan pendidikan.

Proses belajar mengajar merupakan inti proses pendidikan formal di sekolah. Dalam belajar mengajar ada interaksi atau hubungan timbal balik antara mahasiswa dengan dosen, dimana mahasiswa menerima bahan pelajaran yang diajarkan. Mengajar dengan merangsang, membimbing dan mengarahkan mahasiswa mempelajari bahan pelajaran sesuai dengan tujuan. Hal ini sesuai dengan pendapat Trianto (2010) yang menyatakan "Mengajar pada dasarnya meliputi mengajari mahasiswa bagaimana belajar, bagaimana mengingat, bagaimana berfikir dan bagaimana memotivasi diri sendiri tampa ada paksaan tapi penuh kesadaran untuk mencapai tujuan”.

Selama proses pembelajaran Perkembangan Hewan, mahasiswa diharapkan berani untuk bertanya kepada dosen, tentang konsep-konsep yang kurang dipahami. Dengan mengajukan pertanyaan 
sebanyak mungkin sehubungan dengan materi perkuliahan yang diterangkan sangat menunjang pemahaman mahasiswa akan materi perkuliahan. Kemampuan bertanya menunjukkan pikiran yang selalu ingin tahu dan merupakan tanda pembelajar yang baik. Dan mencoba membuat pertanyaan secara tertulis sesuai dengan tingkatan taksonomi Bloom revisi.

Upaya mahasiswa dalam mencapai keberhasilan belajar meliputi mendengarkan perkuliahan dengan serius, menjawab pertanyaan, berpatisipasi aktif dalam proses, mengajukan pertanyaan, mengerjakan tugas-tugas yang diberikan. Mahasiswa yang memiliki semangat belajar yang tinggi akan memberikan masukan dalam bentuk gagasan atau pertanyaan kepada dosen atau kepada kelas tentang kegiatan atau tugas tambahan untuk memperluas dan memperdalam lingkup materi perkuliahan, dengan demikian akan mengasah kemampuan bertanya. Bila mempunyai kesadaran tinggi akan belajar mahasiswa haus akan berbagai aspek yang terkait dengan topik dan mata kuliah yang dipelajarinya. Menetapkan targetnya sendiri melebihi target yang ditetapkan oleh dosen dan Kurikulum. Memcari sendiri materi perkuliahan yang ingin dikuasainya melalui berbagai sumber dan cara menurut inisiatifnya sendiri (Gintings, 2014).

Dosen sebagai pemberi informasi, akan membutuhkan tanggapan dari mahasiswa sebagai alat ukur untuk mengetahui sejauh mana materi pelajaran yang disampaikannya diterima, dipahami dan dimengerti. Sedangkan bagi mahasiswa sendiri, bertanya merupakan salah satu cara untuk memahami pelajaran, menambah wawasan baru dan memantapkan apa yang tadinya masih ragu-ragu atau belum jelas menjadi lebih jelas dan bisa dipahami. Jika interaksi ini tidak berlangsung dengan baik, maka komunikasi yang terjadi saat pembelajaran berlangsung hanya satu arah. Seperti yang kita ketahui bahwa dalam proses pembelajaran itu terjadi interaksi dua arah.
Ini jelas menghambat proses transformasi ilmu yang ada dalam proses belajar mengajar. Mengajak mahasiswa bertanya akan berpengaruh positif pada pembelajaran serta pemahaman terhadap materi. Begitu banyak strategi, pendekatan, model pembelajaran yang digunakan dosen untuk mengundang mahasiswa mau bertanya pada saat pembelajaran berlangsung, namun belum cukup untuk membuat mau bertanya.

Hasil observasi dengan mahasiswa Program Studi Pendidikan Biologi, menyebabkan kesulitan mengungkapkan pertanyaan pada proses perkuliahan, diantaranya: (1) kurang bervariasi metoda dan model pembelajaran yang dilakukan dalam perkuliahan (2) kurang perhatian mahasiswa pada waktu dosen menerangkan dan sedikit fasif (3) kurang percaya diri untuk mengungkapkan pertanyaan di depan teman dan dosen karena takut dianggap salah, (4) mengalami kesulitan mengungkapkan dalam bahasa lisan yang baik ketika bertanya (5) kurang rajin membaca materi perkuliah atau bukan bahan perkuliahan seperti jurnal, majalah adan artikel yang berhubungan dengan materi (6) keinginan bertanya mahasiswa pada proses perkuliahan relative tergantung pada dosen yang mengajar mata kuliah.

Alasannya perlu dilakukan perbaikan agar masalah kemampuan bertanya pada mahasiswa akan dapat diatasi. Cukup beralasan jika dengan pengembangan bertanya dan membuat pertanyaan untuk mata kuiah Perkembangan Hewan, maka produktivitas pembelajaran akan lebih tinggi, karena dengan bertanya: dapat menggali informasi, baik administrasi maupun akademik, mengecek tingkat pemahaman diri, membangkitkan respon belajar, mengetahui sejauh mana keigintahuan setiap individu, mengetahui hal-hal yang diketahui, memfokuskan perhatian, membangkitkan lebih banyak lagi pertanyaan dari mahasiswa, dan menyegarkan kembali pengetahuan yang 
mereka dimiliki. Penelitian terdahulu oleh Cholifah dkk (2013) dengan judul: Analisis Faktor-Faktor Penyebab Kesulitan Siswa Dalam Mengungkapkan Pertanyaan Pada Proses Pembelajaran Biologi Kelas VII SMP Bunda Padang, didapat bahwa hasil dari penilaian berdasarkan kategori level kesulitan bertanya menunjukkan banyak siswa berada di kategori cukup tinggi yaitu $57.35 \%$ dalam membuat pertanyaan. Dari paparan di atas maka tujuan dari penelitian ini mengetahui Profil faktor-faktor kesulitan mengungkapkan pertanyaan pada proses pembelajaran Perkembangan Hewan Mahasiswa Program Studi Pendidikan Biologi.

\section{METODE PENELITIAN}

Penelitian ini telah dilaksanakan pada Program Studi Pendidikan Biologi FKIP-UIR Pekanbar. Pada bulan JuliDesember 2017. Jenis penelitian ini Survei. Instrument yang digunakan dalam penelitian ini ialah angket terdiri dari 57 item pertayaan dibagi menjadi faktor internal dengan jumlah 22 item dan faktor ekternal jumlah 24 item, dan untuk Mahasiswa yang Bertanya dan yang tidak bertanya jumlah 3 item pertanyaan.
Soal yang ditulis dalam proses belajar dari C1,C2,C3,C4,C5 dan C6, wawancara dan dokumentasi. Dari indikator untuk mengetahui jawaban pertanyaan digunakan Skala Likert. Dengan lima katagori, yaitu sangat sering, sering, cukup sering, kadangkadang, tidak pernah. Memberikan checklist $(\sqrt{ })$ pada jawaban yang sesuai menurut responden. Menguji validasi kontruk dan isi di bantu rekan sejawat Tengku Idris S.Pd. M.Pd. (2017). Populasi dalam penelitian ini semua mahasiswa semester III berjumlah 70 orang pada Pendidikan Biologi FKIPUIR. Penelitian ini menggunakan sampel jenuh, semua populasi dijadikan sampel. Tehnik analisis data digunakan peneliti adalah Analisis Deskriftif.

\section{HASIL DAN PEMBAHASAN Data Indikator faktor Internal}

Deskripsi Persentase Profil

Kesulitan Mengungkapkan Pertanyaan Pada Proses Pembelajaran Perkembangan Hewan, pada indikator faktor internal dangan subindikator yang didapat dari hasil penelitian bisa dilihat pada gambar 1 di bawah ini;

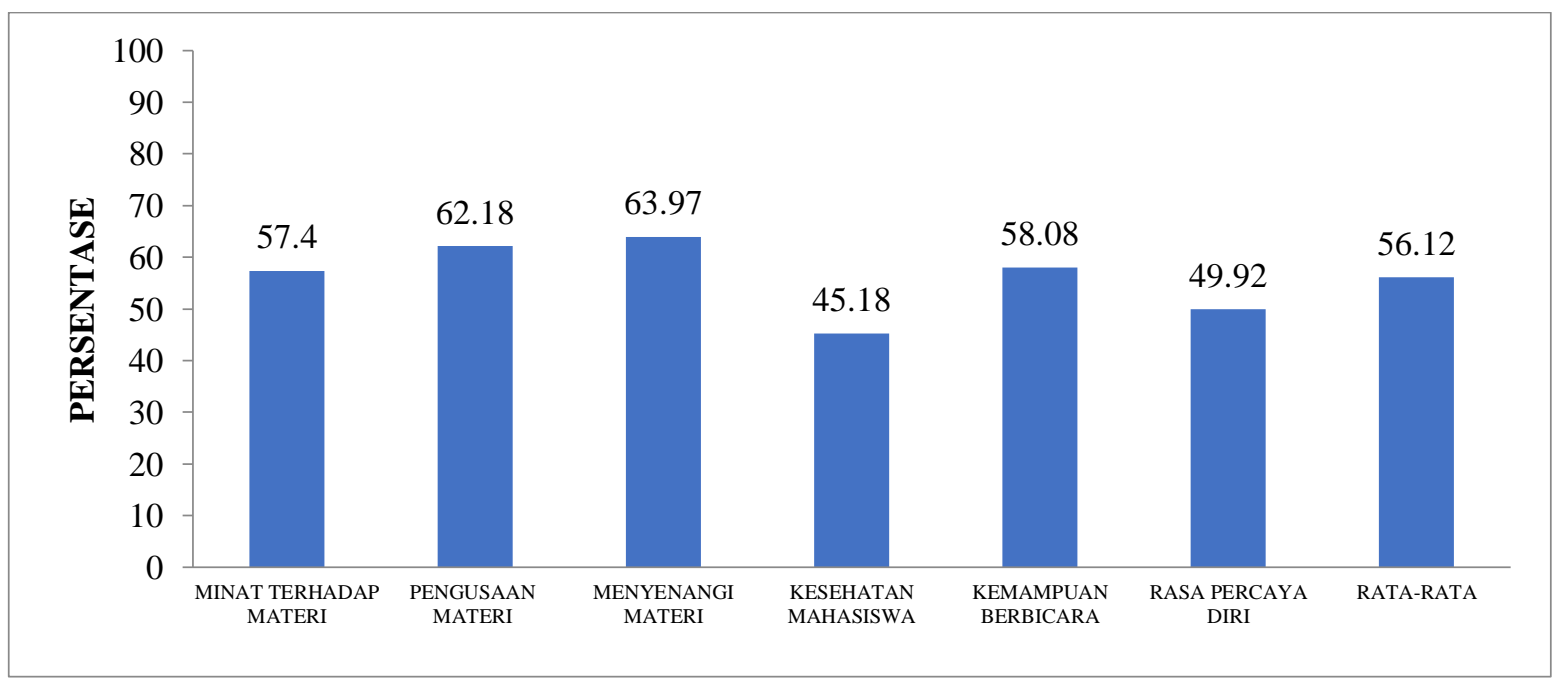

Gambar 1. Grafik Indikator Faktor Internal dengan Rata-Rata Persentase Subindikator

Data dari hasil perhitungan maka persentase terendah pada sub indikator kesehatan mahasiswa dengan nilai
$(45,18 \%)$ kategori cukup, sedangkan persentase tertinggi subindikator menyenangi materi perkuliahan 
Perkembangan Hewan dengan nilai $(63,97$ $\%$ kategori tinggi. Dan rata-rata persentase untuk indikator faktor internal dengan nilai $(56,12 \%)$ kategori cukup.

\section{Data Persentase untuk Indikator Faktor Eksternal}

Sedangkan untuk faktor eksternal dengan subindikator dilihat pada Gambar 2 di bawah ini:

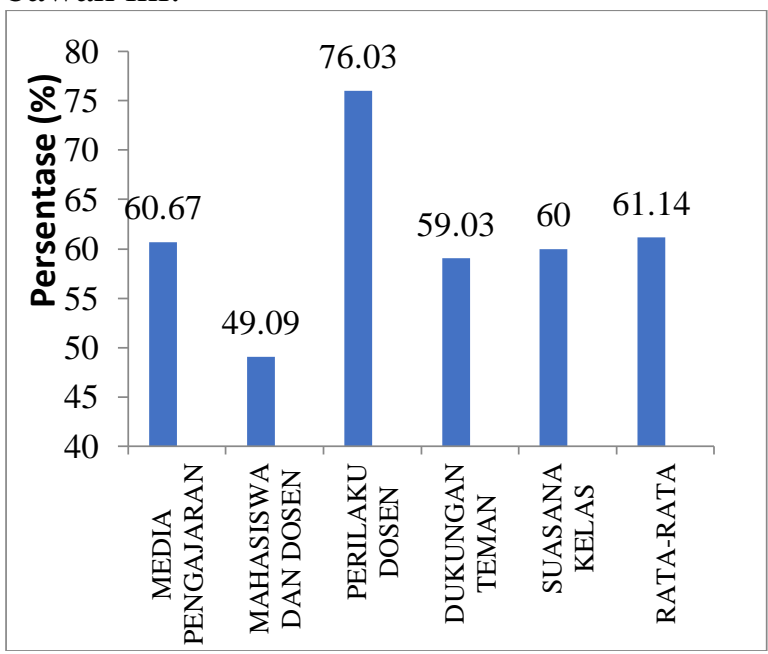

Gambar 2. Grafik Indikator Faktor

Eksternal dengan Rata-Rata Persentase

Subindikator

Data yang didapat nilai persentase terendah pada sub indikator hubungan siswa dengan guru (dosen), (49,09 \%) dengan kategori cukup sedangkan nilai persentase tertinggi subindikator Perilaku guru (dosen) dalam perkuliahan $(76,03 \%)$ dengan kategori tinggi. Dan rata-rata persentase untuk indikator faktor eksternal $(64,14 \%)$ dengan kategori tinggi.

\section{Data Mahasiswa yang Bertanya}

Pada proses pembelajaran bagi mahasiswa pada mata kuliah Perkembangan Hewan yang bertanya dengan 3 pertanyaan dapat dilihat pada gambar 4 di bawah ini.

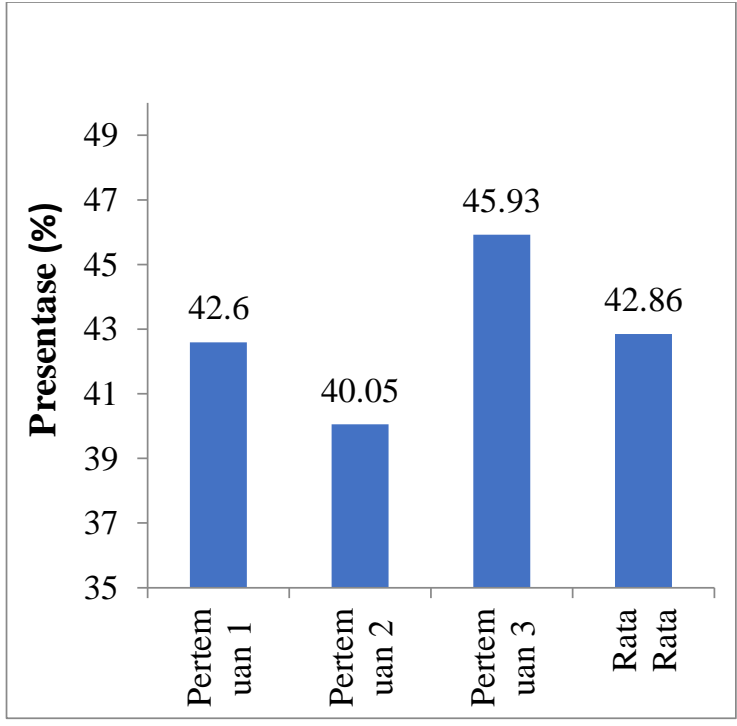

Gambar 4. Grafik Rata-Rata Mahasiswa Bertanya

Data nilai persentase rata-rata bagi mahasiswa yang bertanya dalam proses perkuliahan materi Perkembangan Hewan (angket negatif) terdiri dari 3 pertemuan diantaranya pertemuan I $(71,45 \%)$, pertemuan II $(69,63 \%)$, pertemuan III $(69,87 \%)$ dengan kategori tinggi. Dengan rata-rata $42.86 \%$ dengan kategori cukup.

\section{Data Mahasiswa yang Tidak Bertanya}

Data yang didapat dari proses pembelajaran bagi mahasiswa pada mata kuliah Perkembangan Hewan yang tidak bertanya dengan 3 pertanyaan dapat dilihat pada gambar 3 di bawah ini.

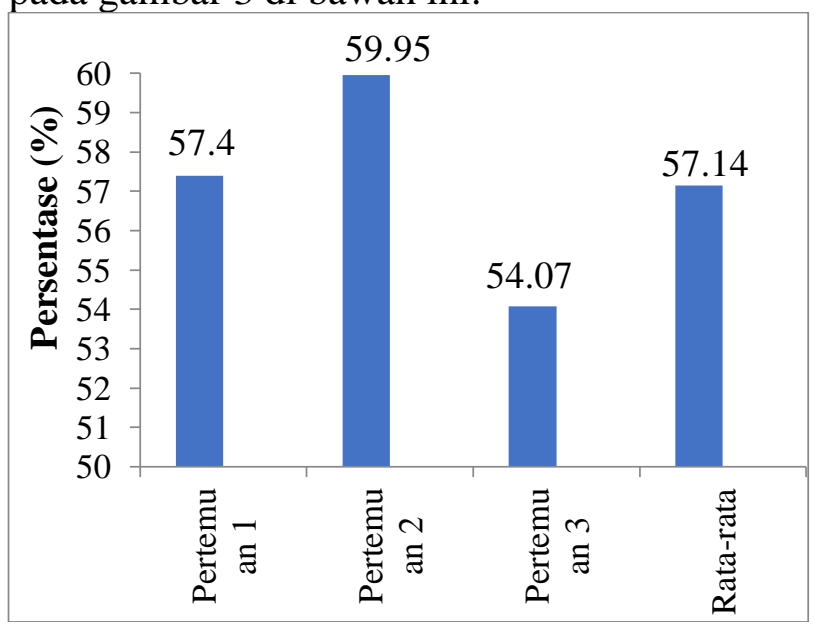

Gambar 3. Grafik Rata-Rata Mahasiswa yang Tidak Bertanya

Data nilai persentase rata-rata bagi mahasiswa yang bertanya dalam proses 
perkuliahan materi Perkembangan Hewan (angket positif), pada pertemuan I $(57,04 \%)$, pertemuan II $(55,95 \%)$, pertemuan III $(54,07 \%)$ dimana ketiganya dengan kategori cukup. Dengan rata-rata $57.14 \%$ dengan kategori cukup.

\section{Data Soal yang Ditulis dalam Proses Perkuliahan}

Data yang didapat dari proses perkuliahan bagi mahasiswa yang membuat pertanyaan (soal) dalam bentuk tertulis dapat dilihat pada gambar 5 di bawah ini;

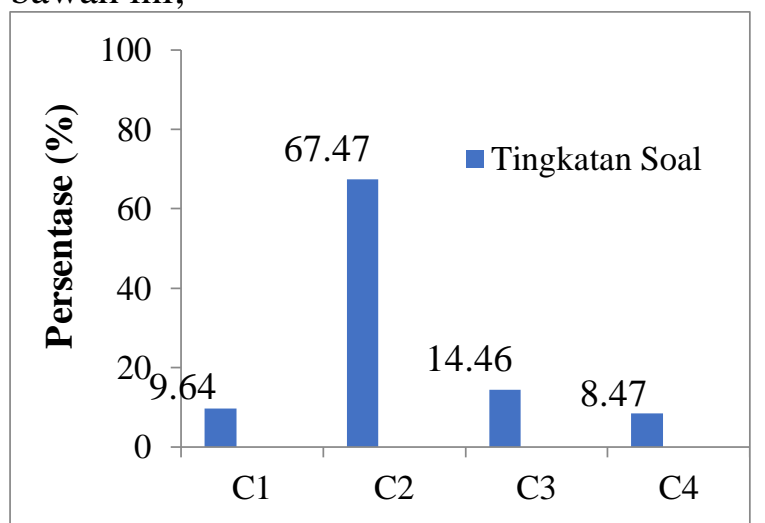

Gambar 5. Grafik Rata-Rata Persentase

Soal yang Ditulis Selama Perkuliahan

Data selama proses perkulihan berlangsung mahasiswa yang menuliskan/mengajukan pertanyaan menurut tingkah laku atas tingkatan atau taksonomi Bloom revisi, urutan kognitif jumlah yang terbanyak soal ditemukan hanya di C2 (67.47\%) dengan katagori Tinggi dan jumlah soal yang terendah $\mathrm{C} 4$ $(18.43 \%)$ dengan katagori sangat rendah.

\section{PEMBAHASAN}

Hasil penelitian tentang Profil Faktor-Faktor Kesulitan Mengungkapkan Pertanyaan Pada Proses Pembelajaran Perkembangan Hewan. Pada indikator faktor internal dengan perhitungannya maka persentase terendah pada sub indikator kesehatan mahasiswa dengan nilai $(45,18 \%)$ katagori cukup, disebabkan jadwal kuliah pagi jam 7.00 wib, tak jarang suka kesiangan bangun tidur ini membuat mahasiswa sering mengabaikan sarapan. Padahal ini aktivitas yang tidak boleh dilewatkan karena secara alamiah, ketika bangun dari tidur, gula darah yang dibutuhkan tubuh untuk membuat otot dan otak bekerja optimal biasanya dalam keadaan rendah. Sarapan dapat membantu tubuh meningkatkan kadar gula darah. Juga membantu membakar kalori, memberikan energi yang butuhkan, sehingga membuat lebih fokus dalam mengikuti perkulihan. Menurut Khairani (2015), didalam belajar faktor internal sangat berpengaruh salah satunya kesehatan, karena belajar tidak hanya menyangkut segi intelek tatapi juga menyangkut kesehatan, kondisi ini mempunyai hubungan timbal balik. Sebab individu didalam hidupnya selalu mempunyai kebutuhan-kebutuhan dan dorongan-dorongan sehingga belajar dapat berjalan secara maksimal. Menurut Higgins dkk ( 2008) kesehatan dalam dunia pendidikan tidak hanya pada kesehatan fisik, namun kesehatan mental baik dari pergaualan yang baik, maupun prbadi yang baik.

Persentase tertinggi subindikator
menyenangi materi Perkembangan Hewan dengan nilai $(63,97$ $\%)$ katagori tinggi. Beragam referensi, yang digunakan untuk perguruan tinggi, contohnya jurnal, buku, modul ajar, buku praktikum, bahan ajar, dan buku teks pelajaran dan dari internet. Materi hendaknya diberikan satu minggu sebelumnya, dengan membuat mind mapping, peta konsep, power point, agar materi tertata dengan baik sehingga mudah untuk dimengerti dan dipelajari lalu dalam proses dilengkapi dengan contoh yang kongkrit sehingga daya imaginasi mahasiswa terexplorasi dengan baik. Melakukan diskusi di kelas dengan katagori mahasiswa (tinggi, sedang dan rendah) agar proses diskusi berjalan dengan maksimal. Mahasiswa diberikan kesempatan untuk bertanya dan menjawab agar kemapuan internalnya terasah seperti percaya diri, mandiri, kreatif, toleransi dapat terbangun dengan baik, Model- 
model perkuliahan yang diterapkan sangat relevan dengan konsep pendidikan yang menyenangkan seperti pembelajaran berbasis masalah, inkuari terbimbing, pembelajaran berbasis proyek dan mengajak dan melatih mahasiswa berpikir kritis dan analisis. Menurut Sokfoon dkk (2012); Ngalimun (2014) dan Slameto (2015) mengatakan bahwa proses pembelajaran yang menyenangkan membutuhkan lingkungan yang kondusif, kinerja dosen yang baik dan pengelolaan materi yang menarik.

$$
\text { Rata-rata persentase untuk }
$$

indikator internal dengan nilai $(56,12 \%)$ katagori cukup. Karena faktor internal terdiri dari faktor fisiologis atau jasmani individu dan faktor psikologis, baik yang bersifat bawaan maupun yang diperoleh, yang terdiri dari faktor intelektif yaitu intelegensi dan bakat serta faktor aktual yaitu kecakapan yang nyata, seperti prestasi. Faktor psikologis lain yaitu faktor non intelektif yaitu komponen kepribadian tertentu seperti sikap, minat, kebiasaan, kebutuhan, motivasi, konsep diri, penyesuaian diri, emosional, penguasaan siswa terhadap materi pelajaran, menyenangi materi pelajaran, kesehatan siswa, kemampuan dalam berbicara, rasa percaya diri, harus dibangun secara nyata melalui interaksi antara orang tua, dosen agar mahasiswa menghadapi kehidupan kampus yang mereka jalani, agar mencapai tujuan yang diinginkan. Menurut Dalyono (2009) Salah satu indikator keberhasilan suatu proses pembelajaran dapat dilihat dari prestasi belajar siswa dimana diketahui kedudukan siswa yang pandai, sedang atau lambat dapat dilihat dari sikap, kebiasaan dan lai-lain yang berhubungan dengan faktor internal

Data yang didapat nilai perhitungan dari faktor eskternal persentase terendah pada sub indikator hubungan mahasiswa dengan guru (dosen), (49,09 \%) dengan katagori cukup diharapkan pola komunikasi manusiawi dosenmahasiswa amat menentukan dalam keberhasilan studi. Karena berkat kersamaan kedua belah pihak, mahasiswa menjadi lebih kritis, transformatif, dan punya hubungan emosional tinggi dalam kehidupannya. Menurut Bovee dan Thill (2012); Ginting (2014) dan Nyadanu (2015) Hubungan mahasiswa dengan dosen yang erat dan positif serta komunikasi yang baik akan berdampak pada peningkatan yang signifikan dalam prestasi akademik mahasiswa.

Sedangkan nilai persentase tertinggi subindikator Perilaku dosen dalam perkuliahan $(76,03 \%)$ dengan katagori tinggi. Dosen harus memiliki kepribadian diantaranya berwibawa, kepribadian yang mantap, matang dan stabil, dewasa, arif, adil dan bijaksana serta berkembang . Karena guru merupakan faktor utama yang bisa mempengaruhi mahasiswa didalam kelas, segala tingkah laku dan cara berbicara seorang dosen pasti akan diperhatikan oleh mahasiswa. Karena kepribadian seorang dosen sangat berpengaruh terhadap mahasiswa maka harus memiliki ciri kepribadian yang matang dan sehat. Gintings (2014) mengatakan banyak hal yang mempengaruhi dosen (guru) sehingga memiliki kepribadian yang unik, lingkup budaya , agama, keluarga, pengalaman akademis, pengalaman kerja dan karakter bawaan yang membentuk cara berpikir, semua akan membentuk gaya dan cara dalam pembelajaran. Setiap dosen (guru) memiliki kepribadian yang dalam beberapa hal membantu penyelenggaraan dalam menyelengarakan pembelajaran walaupun perlu sedikit modifikasi. Menurut Khalid dkk (2011) kualitas pendidikan tergantung pada warganya, kualitas warganya tergantung pada pendidikan dan kualitas pendidikan tergantung pada latar belakang dosen (guru) dan prilaku dosen dalam proses pembelajaran. Guru harus berkomitmen untuk mengerahkan selurus kemampuan terbaiknya serta energi positif kepada mahasiswa dalam proses pembelajaran.

Dan rata-rata persentase untuk indikator eskternal $(64,14 \%)$ dengan 
katagori tinggi. Karena faktor eksternal meliputi sosial, lingkungan keluarga, sekolah, teman, masyarakat, budaya, adat istiadat, ilmu pengetahuan dan teknologi, faktor lingkungan fisik contohnya fasilitas belajar di rumah, di sekolah, iklim dan faktor spiritual serta lingkungan keluarga. Karena belajar merupakan proses aktif, dimana individu tidak hanya menerima, tetapi dituntut pula untuk berolah fikir, rasa untuk memperoleh, dukungan teman dalam pembelajaran begitu juga dengan dosen harus memahami metode pengajaran yang digunakan, media yang digunakan, hubungan siswa dengan dosen, prilaku dalam mengajar, sehingga suasana kelas yang mendukung pembelajaran. Slavin (2000) dalam pembelajaran di kelas dosen hendaknya mampu menciptakan suasana perkuliahan yang kondusif. Suasana yang kondusif dapat membuat rasa nyaman dan merupakan gambaran sikap dosen dalam di kelas yang memungkinkan peserta didik (mahasiswa) tidak tegang dalam belajar, akan dapat mendorong peserta didik berprestasi dalam belajar.

Rata-rata mahasiswa bertanya selama 3 kali pertemuan dalam kategori cukup (42.86\%). Bertanya merupakan cara dasar untuk mengumpulkan informasi. Tetapi diperlukan kemampuan untuk dapat melakukannya dengan baik. Mengajukan pertanyaan merupakan cara yang mudah untuk mengajak sesama mahasiswa bercakap-cakap. Sebelum dapat mulai mengajukan pertanyaan secara efektif, perlu mengetahui apa yang akan ditanyakan karena pertanyaan memerlukan jawaban penuh yang menggunakan pengetahuan yang didapat dari membaca, mendengar, melihat dan pengalaman. Pentingnya mahasiswa bertanya juga untuk mengembangkan pola berpikir sebagai kesempatan untuk menunjukkan sikap, keterampilan dan pemahamannya atas substansi pembelajaran yang diberikan, membangun sikap keterbukaan untuk saling memberi dan menerima pendapat atau gagasan, membangun rasatanggung jawab terhadap pertanyaan yang diajukan, membiasakan peserta didik berpikir spontan dan cepat, dan sigap dalam merespon persoalan, serta untuk membangkitkan keterampilan dalam berbicara, ini harus dilatih terus sehingga di dapat hasil proses lebih maksimal dalam kemampuan dan kemauaan bertanya. Menurut Handayani (2014) keterampilan bertanya merupakan bagian tidak terpisahkan dalam rangka meningkatkan kualitas proses dan hasil pembelajaran sekaligus merupakan bagian dari keberhasilan dalam pengelolaan instruksional dan pengelolaan kelas. Diperkuat oleh Zaifbio (2013) Dalam mengajukan pertanyaan memerlukan beberapa teknik, begitu juga pada mahasiswa. Ketika mengajukan pertanyaan pasti menggunakan teknikteknik tertentu.

Data yang didapat nilai persentase rata-rata untuk mahasiswa yang tidak bertanya, dari 3 kali pertemuan dengan 3 item pertanyann didapat rata-rata $(57.14 \%)$ katagori cukup. Jika mahasiswa masih belum mampu merubah kondisi dalam proses pembelajaran, maka kemampuan bertanya akan rendah ketika akan dihadapkan pada keadaan yang sebenarnya, dan kurangnya keterampilan bertanya mahasiswa pada materi yang terkait. Keberanian mahasiswa bertanya dalam proses belajar di kelas begitu rendah. Masalah ini dapat dipengaruhi oleh faktor internal mahasiswa yang bersangkutan diantaranya, mahasiswa sudah paham sekali, tidak paham, malu, takut sama dosen, malas bertanya, menunggu teman lainnya untuk bertanya terlebih dahulu, Lebih baik mencari jawaban atas pertanyaannya sendiri lewat buku atau teman. Sedangkat faktor eskternal; kurang montivasi dari dosen, suasana belajar dan fasilitas, upaya menumbuhkan keberanian bertanya

mahasiswa dan latihan dengan pembelajaran inkuari. Menurut Sadiman (1994) bertanya merupakan ucapan verbal yang meminta respon dari seseorang yang dikenal. Respon yang diberikan dapat 
berupa pengetahuan sampai hal-hal yang merupakan hasil 3 pertimbangan. Berdasarkan pendapat diatas maka dapat disimpulkan bahwa bertanya merupakan proses mencari informasi agar memahami suatu. Indikator kemampuan bertanya ada empat yaitu mengajukan pertanyaan kepada guru, mengajukan pertanyaan dengan bahasa yang tepat, percaya diri dalam mengajukan pertanyaan, menghargai teman.

Data selama proses perkulihan berjalan mahasiswa yang mampu menuliskan pertanyaan dengan urutan C1 (Pengentahuan), C2 (Pemahaman), C3 (Aplikasi), C4 (Analisis), tapi jumlah soal yang terbanyak hanya di level C2 $(67,47$ $\%)$ dengan katagori Tinggi, karena kemampuan untuk menangkap arti suatu materi atau informasi yang dipelajari mahasiswa sudah memasuki satu level lebih tinggi setelah melewati level hafalan. Tapi secara akademik sesuai dengan level pendidikan hanya sampai taraf $\mathrm{C} 2$ itu sangat rendah, diharapkan mahasiswa yang ada di Program Studi Pendidikan Biologi semester III dengan mata kuliah yang berbeda selama proses perkuliah dengan materi yang ada kedapannya bisa membuat soal sampai level C5 dan ke level C6. Untuk itu dilatih kemampuan bertanya terutama penekanan untuk level soal yang lebih tinggi dengan cara memberikan materi dalam bentuk kasus, sehingga meninggikan daya analisis. Disini mahasiswa hanya mampu memahami dan mencerna makna yang terkandung dari pesan yang sudah dihafalkan (mereka hanya mampu menghubungkan pengetahuan baru dengan pengetahuan lama. Kemampuan ini umumnya mendapat penekanan dalam proses belajar mengajar. Mahasiswa dituntut memahami atau mengerti apa yang diajarkan, mengetahui apa yang sedang dikomunikasikan dan dapat memanfaatkan isinya tanpa harus dihubungkan dengan hal lain. Untuk kedepannya mahasiswa harus dilatih terus didalam proses perkuliahan, agar kemampuan kognitifnya bisa maksimal sehingga mampu mengajukan pertanyaan dilevel yang diharapkan. Menurut Andersen \& Krathwohl (2010) memahami bila mereka dapat mengkontruksi makna dari pesan-pesan pembelajaran baik bersifat lisan, tulisan atau grafis yang disampaikan melalui pengajaran sehingga mahasiswa memperoleh makana dari materi perkuliahan yang telah dipelajari.

Sedangkan untuk jumlah soal level yang terendah C4 $(1,20 \%)$ dengan katagori sangat rendah, Untuk dapat sampai pada level yang $\mathrm{C} 4$ yang tinggi dan level $\mathrm{C} 5$ dan C6, mahasiswa harus mampu mengombinasikan beberapa permasalahan menjadi satu rangkaian yang utuh, sehingga terbukti bahwa pesan yang didapat memiliki keterkaitan antara satu pesan dengan pesan yang lain. Untuk sampai ke level ini mahasiswa dituntut di dalam proses perkuliahan memberikan pengayaan materi dengan berbagai referensi, memunculkan materi dalam bentuk permasalahan dan dibiasakan diajak berpikir kritis tingkat tinggi, tapi dengan kondisi faktor internal dan faktor eksternal mahasiswa maka hal ini akan sangat berpengaruh terhadap proses perkuliahan. Menurut Andersen \& Krathwohl (2010), menyatakan pada tingkat menganalisis mahasiswa harus mampu menentukan potongan-potongan informasi yang relevan atau penting, menentukan cara-cara untuk menata potongan imformasi, dan menentukan tujuan dibalik imfomasi tersebut. Dari penelitian dapat dikatakan bahwa FaktorFaktor Kesulitan Mengungkapkan Pertanyaan bagi mahasiswa jelas dipengaruhi oleh faktor internal dan faktor eskternal, jika kedua faktor ini tidak bisa diatasi dengan baik oleh mahasiswa akan berpengaruh terhadap pertanyaan yang diajukan didalam proses belajar mengajar. Dimana data hasil penelitian ini diperkuat oleh penelitian Rahmi (2016) "Analisis Ketrampilan Bertanya Siswa Pada Konsep Gerak dan Starategi Pembelajaran Question Student Have. Dalam penelitian ini bertujuan untuk mengetahui kualitas 
dan kuantitas ketrampilan bertanya siswa berdasarkan taksonomi bloom revisi dengan menerapkan strategi pembelajaran question student have pada konsep sistem gerak. Penelitian dilakukan di MAN Tangerang pada kelas XI IPA semester 1 tahun pelajaran 2015/2016. Dimana keterampilan bertanya siswa masih tergolong rendah yang didominasi level kognitif C2 (memahami).

\section{KESIMPULAN}

Dari hasil data penelitian diperoleh pada indikator faktor internal dengan ratarata persentase dengan nilai $(56,12 \%)$ katagori cukup, dan rata-rata persentase untuk indikator external $(64,14 \%)$ dengan katagori tinggi. Bagi mahasiswa yang bertanya dari 3 item pertanyaan dengan rata-rata $(42,86 \%)$ katagori cukup. Mahasiswa yang tidak bertanya dari 3 item pertanyaan dengan rata-rata $(57,14 \%)$ katagori cukup. Selama proses perkulihan berjalan mahsiswa yang mampu menuliskan pertanyaan yang tertinggi hanya di level C2 (67,47 \%) dengan katagori Tinggi, Sedangkan untuk jumlah soal level yang terendah C4 $(1,20 \%)$ dengan kategori sangat rendah.

\section{REFERENSI}

Andesrson, L.W., \& Krathwohl, D.R,. (2010). Pembelajaran Pengajaran dan Penilaian. Yokyakarta. Pustaka aksara.

Bovee, Courtland L \& Thill, John V.

(2012). Komunikasi Bisnis.

(Penterjemah: Doddi Prastuti, dkk).

Jakarta: Indeks

Cholifah, S., Hendri, W., \& Deswati, L. (2013). Analisis Faktor-faktor Penyebab Kesulitan Siswa dalam Mengungkapkan Pertanyaan pada Proses Pembelajaran Biologi Kelas VII SMP Bunda Padang. E-Journal Universitas Bung Hatta. Vol. 2, No. 4, 2013, h.11

Dalyono, M. (2009). Psikologi Pendidikan. Jakarta: Rineka Cipta.
Darmadi, H. (2009). Kemapuan Dasar Mengajar. Bandung: Alfabeta

Darmadi. (2013). Metode Penelitian Pendidikan dan Sosial. Bandung: Alfabeta

Gintings, A. (2010). Esensi Praktis Belajar dan Pembelajaran. Bandung. Humaniora

Handayani, S. (2014). Peningkatan Kompetensi Pedagogik Guru IPS Sekolah Dasar Melalui Penerapan Keterampilan Mengajar. Jurnal Universitas Jember. Jember. $15 \mathrm{hlm}$. Diunduh 23 Desember 2017 jam 9 malam

Higgins,C., Lavin,T.,\&Metclafe,O. (2008). Health Impact of Education. Institute of Public Health in Ireland . November 2008.

Khairani, M. (2015). Psikologi Komunikasi dalam Pembelajaran. Yogyakarta: Aswaja Pressindo.

Khalid, A., Yasmin, S \& Azeem, M.(2011) Impact of Teacher's Background and Behavior on Students Learning. International Journal of Human Resource Studies. ISSN 2162-3058 2011, Vol. 1, No. 2

Ngalimum. (2014). Strategi dan Model Pembelajaran. Penerbit Pressindo. Yokyakarta.

Nyadanu, S.,D.,Garglo,M.,Y., Adampak,T., \&Garglo,R.,L. (2015). The Impact of Lecturer-Student Relationship on Self-Esteem and Academic Performance at Higher Education. Journal of Social Science Studies. ISSN 2329-9150 2015, Vol. 2, No. 1.

Rahmi, Q. (2016). Analisis Keterampilan Bertanya Siswa Pada Konsep Gerak dan Strategi Pembelajaran Question Student Have. Fakultas Tarbiyah dan Keguruan UIN Syarif Hidayatullah. Jakarta

Rudy, Teuku May. (2005). Komunikasi dan Hubungan Masyarakat Internasional.Bandung:PT. Refika Aditama 
Sadiman (1994). Interaksi dan Motivasi Belajar Mengajar. Raja Grafisindo Persada: Jakarta.

Slameto. (2015). Belajar dan FaktorFaktor Yang Mempengaruhi. Jakarta: Rineka Cipta: Rajawali Pers

Slavin, R. E. 2000. Educational Psychology: Theory and Practices. New York: Allyn \& Bocan.

SokFoon,Y.,SyeZin,J.H., \& Yinfah,B.,C. (2012) Student Evaluation of Lecturer Performance Among Private University
Students.Canadian Social Science. Vol. 8, No. 4, 2012, pp. 238-243

Tiarti, S. danWijaya ,A.,2008. Hubungan Beberapsa Ciri Perilaku Guru dengan Prestasi Siswa. "www.webmaster F.Psi Untar id. (2 Mai 2018)

Trianto. (2010). Mendesain Model Pembelajaran Inovatif-Progresif. Jakarta: Kencana

Zaifbio. 2013. Keterampilan Bertanya. Http://zaifbio.wordpress.com/ 2013/05/14/keterampi-lanbertanya/. 